Beta-blockade and Myocardial Infarction

SIR,-We appreciate the reply of Dr. K. M. Fox and his colleagues (26 April, p. 193) to our letter (15 March, p. 627).

(1) We cannot accept that a prospective (randomized control, double-blind) trial of beta-blockers in patients with coronary heart disease would be unethical. Dr. Fox and his colleagues state that "the beneficial effects of beta-blockade for stable and unstable angina are now well proved and such a study would mean withholding this form of therapy from half the patients." Even if one studied only patients with angina, the faot that some patients appear to improve symptomatically on betablockade goes no way towards resolving the controversy as to whether such treatment alters montality. This controversy is our very reason for considering a prospective study both ethical and necessary.

(2) While we are grateful for the additional information about the comparability of Dr. Fox and his colleagues' control and beta-blocker groups, the possibility of a difference in prognostic composition of the two groups cannot be answered without prospective follow-up.

(3) We are sorry that Dr. Fox and his colleagues do not appear to understand the term "too 'soft' an end point." The duration of their patients' chest pain is irrelevant to the fact that "coronary insufficiency" remains an unconfirmed symptom. We do not understand how the fact that the definition of acute coronary insufficiency "varies throughout the literature" justifies the creation of new and potentially more confusing diagnostic terms.

(4) It is fortunate that the consecutive rather than random selection of controls may not have prejudiced the results of their study. We hope that Dr. Fox and his colleagues would concede that random selection of controls is preferable.

(5) The fact that our observaion that the acute myocardial infarction mortality appeared to be twice as high in the betablocked patients as in the control group "is not supported statistically" is not surprising in view of the small numbers of patients studied. The observation still stands and deserves further study with a larger group of patients.-We are, etc.

IAN M. GRAHAM NOEL HICKEY RISTEARD MULCAHY St. Vincent's Hospital and University College, Dublin

GIIbERT MacKENZIE

Queen's University,

Belfast

\section{Geriatric Admissions}

SIR,-Miss Mary Inglis (10 May, p. 338) quite correctly points out that the wishes of geriatric partients should be respected, but I do not agree that the geriatrician should be expected to prescribe "squalid" living conditions for them even if they have no desire for change. This view is taken because for them life becomes a struggle against increasing physical and mental disability leading to loneliness and social isolation giving rise to "rejeotion syndrome." If patients could be encouraged to be admitted to hospital as soon as required, many could return to satisfactory living conditions after treatment and enjoy a healthier and happier life.

It is unfortunate that some admissions to the geriatric unit are due to pressure from relatives or colleagues in acute specialties (as suggested by Miss Inglis), but it is important that the admission should be at a time when the patient needs it and not necessarily due to pressure from any person, because following rehabilitation many may return to the community. This, of course, can be done only if the facilities and staff are adequate. There is a great need to improve the standard of geriatric care, both in the hospital and the community. The present generation of elderly people were not fortunate enough to have a high standard of education in their early life, and their attitude towards medical care and authority is influenced by their experience of life in the past, which included economic hardship and two world wars. ${ }^{1}$ There is evidence that the present generation of people are getting more and more sophisticated in their demands for care in hospital and in the community and this will definitely increase further in the future.

It is true that the elderly patients should be free to decide things for themselves, but the profession cannot prescribe "squalid" living conditions even if some of the elderly would prefer it.-I am, etc.

t. Luke's Hospital

N. K. Chakravorty Huddersfield 1 Portsmouth, O. H. D., Modern Geriatrics, 1972 ,
$2,39$.

\section{Aetiology of Chronic Renal Failure and} Renal Osteodystrophy

SIR, - We have read the observations of Dr. J. A. Kanis and his colleagues (15 March, p. 628) with interest, particularly since they have compared our findings ( 7 December 1974 , p. 557) with their own and those of Pendras. ${ }^{1}$ Unfortunately, marked differences between these series and our own with respect to clinical management and method of analysis make comparison inappropriate. Pendras made no attempt to control plasma phosphate $(2 \cdot 2-3.0 \mathrm{mmol} / 1 \quad(6 \cdot 9-9 \cdot 3 \mathrm{mg} / 100$ $\mathrm{mi}$ )) whereals we have (average $1.45 \mathrm{mmol} / 1$ $(4.5 \mathrm{mg} / 100 \mathrm{ml})$ ). Dialysate calcium in Pendras's and the Oxford series was 1.5 mmol $/ 1(6.0 \mathrm{mg} / 100 \mathrm{ml})$, while the dialysate calcium in our patients has been $1.88 \mathrm{mmol} / 1$ $(7.5 \mathrm{mg} / 100 \mathrm{ml})$ for the past six years.

We thought that our observations with respect to the absence of erosions in nine male polycystic partients were of interest, firstly because this group, though small, was homogeneous with respeot to age, sex, and disease, and secondly, because none of the nine polycystics developed erosions over the six-year period of study. The 50 age-andsex-matched controls were, of course, heterogeneous with respect to the original kidney disease. It is still exceptionally difficult to define original diseases in dialysis patients so that the need emphasized by Dr. Kanis and his colleagues for comparison of the polycystics with homogeneous groups, though logical and undoubitedly well meant, is virtually impossible. They have attributed homogeneity to patients with interstitial nephnopathy diagnosed on history and radiology. However, these criteria are insufficient, since interstitial nephritis has at least 24 distinct aetiologies, many of which lead to chronic renal failure. ${ }^{2}$ In the circumstances of our clinical study we still feel that polycystic disease may protect against erosions, since erosions did not occur in this group and since age and sex were not responsible for their absence polyoystic disease might be. It has been suggested elsewhere ${ }^{3}$ that removal of polycystic kidneys on dialysis might cause an acute deficiency of 1,25-dihydroxycholecalciferol. It is possible that polycystic kidneys may have marginal capability for producing the active metabolite of vitamin $\mathrm{D}$ and hence for calcium absorption and protection against secondary hyperparathyroidism. Dialysis conditions are never ideal and vary considerably between units, so any advantage of polycystic disease may be lost by the use of low dialysate calcium, as in the Oxford patients.

In conclusion, afiter perusal of their short report ${ }^{4}$ and abstract $^{5}$ we agree that Dr. Kanis and his colleagues are bound to conclude that in their programme polycystic disease does not protect against erosions; however, in our own patients under different conditions a protective effeot may be hypothesized, provided age and sex are accounted for and the disease is uncomplicated by severe infection.-We are, etc.,

JOHN MOORHEAD G. L. W. TATLER STEPHEN FARROW R. A. BAILlOD Royal Free Hospital,

M. R. WIILS

\section{Pendras, J. P., Archives of Internal Medicine, 1969, 124, 312 \\ M. B. Strauss, and L. G. Welt Boston, ed. M. B. Strauss, and L. G.
Breun, vol. 1, p. 667,1971 . \\ Cheigh, J. S., et al., Urology, 1973, 2, 121 \\ Henderson, R. G., et al., Proceedings of the Royal Society of Medicine, 1974, 67, 38. \\ Henderson, R. G., Ledingham, J. G. G., and
Woods, G. G., Kidney International, 1974, 6, 62 .}

\section{Fatty Acid Composition of Adipose Tissue} in Newborn Infants

SIR,-Further to the article by Dr. Elsie M. Widdowson and others "Body Fat of British and Dutch Infants" (22 March, p. 653 ) in which significant differences are reported between British and Dutch infants at birth, we have made observations on 16 babies born in London in 1972 as part of a study on infant nutrition. ${ }^{1}$ Our values resemble those found in Dutch babies by Dr. Widdowson and her colleagues and differ from their findings in British babies.

We studied eight term light-for-dates babies (gestation 38 completed weeks, weight for gestational age below 10th centile), three preterm (36 weeks) light-for-dates babies, and five preterm (32-35 weeks) appnopriateweight-for-dates babies. The parents gave informed consent for sampling of adipose tissue from the baby's thigh using a no. 1 needle during the first day of life, and triglyceride was analysed as fatty acid methyl esters by gas chromatography. ${ }^{2}$ The table shows the fatty acid composition of the adipose tissue; the results of Dr. Widdowson and her colleagues and three American studies $^{3-5}$ are shown for comparison.

We do not know the reason for the difference between our findings and those reported by Dr. Widdowson and her col- 